UDK: 339.138:669.2

Originalni naučni rad

Godina XV

Broj 1

Str $1-19$

doi: 10.5937/poseko19-31611

PhD Dragica Stojanović, assistant professor ${ }^{1}$

Megatrend University, Faculty of Management Zajecar, Zajecar

PhD Ivan Jovanović, full professor ${ }^{2}$

University of Belgrade, Technical Faculty in Bor,

Engineering Management Department, Bor

\title{
COVID-19 PANDEMIC AND COMMODITY MARKET INSTABILITY: EVIDENCE FROM THE LONDON METAL STOCK EXCHANGE
}

\begin{abstract}
The paper provides insight into the behavior of non-ferrous metal prices on the London Stock Exchange during the health crisis caused by the spread of coronavirus in the period January 22 - October 30, 2020. The aim of this paper is to determine a statistically significant relationship between the number of confirmed cases of COVID-19 and non-ferrous metals prices copper, aluminum, zinc, nickel, lead and tin. A simple linear regression was used in the paper to obtain results. Following the report of the World Health Organisation and the introduction of restrictive measures to prevent the spread of coronavirus, the results of the regression support the fall in nonferrous metals prices on the London Stock Exchange. Also, the results suggest that the measures taken to address the negative economic consequences of the health crisis are associated with rising non-ferrous metal prices. As the economic impact of the pandemic is still uncertain, through an indicative review of current impacts, the conducted research also provides an opportunity to predict the price of non-ferrous metals in the
\end{abstract}

\footnotetext{
${ }^{1}$ dragica.stojanovic@fmz.edu.rs

2 ijovanovic@tfbor.bg.ac.rs
} 
future. The assumption that price stability in the metal market depends on the degree of control of pandemic COVID-19 provide a basis for future research.

Key words: COVID-19 pandemic, commodity market, nonferrous metals price, simple linear regression

\section{INTRODUCTION}

In 2020 the world entered the largest global deadly pandemic crisis after more than a century (the last one was the Spanish flu pandemic in 1918). The outbreak of coronavirus (COVID-19) was in China at the end of 2019 and in less than three months it spread to Asia, Europe, North America and Latin America. As a result of the huge amount of infections by May 2020, more than 6 million infected and more than 300,000 dead people were recorded worldwide (Johns Hopkins University \& \# 38; Medicine, 2020).

The World Health Organisation (WHO) officially declared the outbreak of COVID-19 a pandemic on March 11, 2020. Accordingly, the Organisation for Economic Co-operation and Development (OECD) reports that the economic turmoil is greater than the global financial crisis during 2007-2009 (BBC BusinessNews, March 23, 2020). Also, the International Monetary Fund (IMF) describes it as "the coronavirus pandemic has fueled an economic downturn that the world has not experienced since the Great Depression" (Reuters Business News, April 9, 2020). To stop the spread of the virus, governments in the countries with confirmed COVID-19 cases require people to stay at home and maintain social distance on a daily basis (Wilder-Smith \& \# 38; Freedman, 2020). In addition, countries issue executive orders to severely restrict travel and personal commercial activities, which leads to the complexity of the global supply chains, and rapid decline of the global economy (McKibbin \& \# 38; Fernando, 2020).

In fact, the COVID-19 pandemic has introduced great uncertainty into supply chains and especially into the global metal industry market. The security of the metal supply chain is undermined by the fact that China produces about 20 percent of intermediary products that are a critical element of the global metal and metal products sector (UNCTAD, 2020). All of these government actions have created more uncertainty, worsened confidence, increased risk aversion, and deepened turmoil in global stock markets. Namely, the direct effects of social distancing measures can have a negative impact on stock market returns and thus, economic activity. On the other hand, the indirect effect of the government actions is channeled by reducing the intensity of the COVID-19 outbreak. Based on recent literature 
reporting that stock exchanges around the world responded to the COVID-19 pandemic with strong negative returns (Baker et al., 2020; Iyke 2020a; Iyke 2020b; Reilly 2020; Saadat et al. 2020), the assumption is that if strict government actions reduce the intensity of local outbreaks, then they weaken the negative market reaction to the growth of confirmed COVID-19 cases.

Since stock markets have become extremely unstable and unpredictable and the economic impact of the pandemic is still uncertain, the aim of the paper is to determine a statistically significant relationship between the COVID-19 pandemic based on data for the period January $22-$ October 30, 2020 (the number of confirmed cases of COVID-19) and the price of non-ferrous metals on the London Metal Exchange.

Having in mind that the disease has caused extreme uncertainty that could bring the world to the brink of a terrible crisis, the authors want to answer the question of how much and to what extent the number of confirmed cases affects the price of copper, aluminum, zinc, nickel, lead and tin on the London Stock Exchange. In this way, the paper joins earlier research and expands the literature on the stock market response to the COVID-19 pandemic.

The rest of the paper is organized as follows. After the introductory part, in section 2, we pay attention to the earlier research in this area, which was used as a basis for presenting theoretical arguments in this paper. Section 3 explains the data and methodology applied. Sections 4 and 5 present a review and discussion of empirical results, while section 6 concludes the research

\section{LITERATURE REVIEW}

Unlike earlier global pandemics, COVID-19 stands out as the most influential, and this time it is really different. By analyzing previous research, we come to the conclusion that the COVID-19 epidemic has different impacts on people, societies, and economic expectations, which was proven in the study by Baldwin and Veder di Mauro, 2020. Namely, the results of their study provide evidence that COVID-19 has a negative impact on various economic aspects.

According to Ji et al. (2020), one of the most visible effects of the COVID-19 pandemic and declining economic activity, was a drastic drop in prices of many commodities on the stock market, as was the case with the price of a barrel of crude oil, which fell from more than 65 USD in early 2020 to less than 20 USD in mid-April, lower than during the 2007-2009 economic crisis. 
Salisu et al., (2020a) in their study using the panel VAR model, have proved that oil and stock markets can have greater initial and prolonged effects of intrinsic and cross shocks during the pandemic compared to the period before.

The fall in oil prices was also confirmed in the research of Albulescu (2020), Gkillas et al. (2020), Torun et al. (2020) and Wu et al. (2020). This is consistent with the findings of Baker et al. (2020), stating that COVID-19 has caused more dramatic and frequent daily stock market changes than any other disease before.

Also, the World Bank (2020) announced a significant drop in the price of other commodities, such as agricultural products (cereals, edible oils, beverages, fertilizers), metals (copper, aluminum, and even precious metals other than gold), during the spread of the COVID-19 disease. Several studies have confirmed that gold still possesses characteristics of the protection and safe haven during this pandemic (Conlon and McGee, 2020; Corbet et al., 2020; Yarovaya et al., 2020).

In addition to the reaction of commodity markets, the Goodell study (2020) suggests significant reactions in financial markets due to the spread of coronavirus. Namely, earlier health crises did not lead to social distancing, which could be one of the main reasons for panic and fear, and therefore, negative reactions of stock exchanges.

\section{RESEARCH METHODOLOGY}

\section{Data}

The Center for Systems Science and Engineering (CSSE) at Johns Hopkins University (JHU) collected the data on the number of confirmed cases of COVID-19 for the period from January 22 to October 30, 2020. Also, official prices for non-ferrous metals copper, aluminum, zinc, nickel, lead, and tin expressed in US\$ per tonne were taken on a daily basis from the site the London Metal Exchange (LME). From the data collected in the observed period, the data for weekends and public holidays were omitted because the data were not published on the LME. For this reason, the data for COVID-19 available for each day were adjusted to follow the available data on the price of metals on the stock exchange. After corrections, the sample size for the observed period is 197.

The events in relation to which the price behavior of non-ferrous metals (Copper, Aluminum, Zinc, Nickel, Lead, and Tin) is observed, influenced the division of the research period. The sample is divided into three parts, i.e. three periods. The key points for dividing the research period 
are the spread of coronavirus and the health and economic measures taken to mitigate the consequences of the COVID-19 pandemic. The events are defined based on the reports by the Health World Organisation (WHO), the International Monetary Fund, and the European Central Bank (ECB). The size of the first part of the sample is 43 and refers to the research period from January 22 to March 22, 2020. The second part of the sample is size 118 and refers to the research period from March 23 to September 10, 2020. The third part of the sample is size 36 and includes the research period from September 11 to October 30, 2020. The following were selected for reference events:

January 22 to March 22, 2020 - The WHO Mission in China issued a statement saying that there is evidence of human-to-human virus transmission in Wuhan and a declaration of a state of emergency in the city. At the same time, the spread of coronavirus is leading to the closure of economies worldwide. Mass quarantines around the world and the approaching date of the proclamation of the pandemic on March 11, 2020 caused a decline in industrial production and in demand for metals. As a result of the measures taken around the world, there was a sharp drop in nonferrous metals prices on the stock exchange.

March 23 to September 10, 2020 - A gradual increase in prices of non-ferrous metals copper, aluminum, zinc, nickel, lead, and tin began on March 23 when a large number of finance ministers and bankers from central banks of 20 largest world economies made decisions to support the economies hit by the COVID-19 pandemic. That led to the lifting of the blockade and the resumption of economic activities in China, first in Wuhan, after 75 days of quarantine (April 7), where most of the industry is situated. All these developments led to an increase in demand for steel ores. Further growth in metal prices was strongly supported by the reopening of the Chinese market as well as the government's stimulus packages taken to boost China's economy in February and March. In addition, as a result of quarantine and isolation of the rest of the world, there were restrictions in supply, and thus, the price of metals on the stock exchange increased. After the period, most countries started the unlocking process in May, so that the expected improvement in demand for metals was reflected in the rise of stock market prices in the coming period. The rise in the stock market prices was also supported by the increase in China's demand for metals due to investments in infrastructure (construction of bridges, roads, utilities, broadband services, and railways across the country). The end result of the activities undertaken in China is a further increase in the prices of metals on the stock exchange.

September 11 to October 30, 2020 - A new coronavirus attack (third wave) with a record number of infected people in European countries. Also, 
the number of newly infected people worldwide is growing, new, stricter progressive restrictions are being introduced due to the spread of the coronavirus epidemic, and some countries are prolonging the state of emergency (Romania until mid-November). All these events lead to the stagnation of the price of metals on the London Stock Exchange.

\section{Research model}

This model consists of seven variables: one independent, which refers to the number of confirmed COVID-19 cases, and six dependent, which refer to the prices of copper, aluminum, zinc, nickel, lead and tin. The relationship between the number of confirmed COVID-19 cases and the price of metals is checked by regression analysis, as one of the most used statistical methods, and which is widely applied both in economics and in other social sciences.

Regression analysis is used in the paper due to the assumption that there is a linear relationship between the independent variable (X) and the dependent variable (Y). Regression analysis is a set of statistical methods that show if there are connections between the observed phenomena and what they are like in shape (rectilinear-linear, curvilinear-nonlinear, and spatial) and direction (positive or negative). The applied statistical method enables the prediction and evaluation of a single phenomenon based on the value of another phenomenon (or group of phenomena). When we observe two phenomena between which there is a linear (rectilinear) connection, it is a simple linear regression. The simple linear regression model can be expressed by regression equation (1), as:

$$
Y_{i}=\beta_{0}+\beta_{1} \cdot X_{i}+\varepsilon_{i} \quad i=1,2, \ldots, N
$$

where are:

Yi - i-th value of the dependent (or response) variable variable

$\mathrm{Xi}$ - i-th value of the independent (or predictor or explanatory)

$\beta 0$ - regression parameter (the y-intercept of the regression line)

$\beta 1$ - regression parameter (slope)

\&i - the error of the estimate

$\mathrm{N}$ - the size of the base set

Based on equation (1), the simple linear regression model for this study can be presented as follows:

$$
\text { Price }_{i}=\beta_{0}+\beta_{1} \cdot \text { Confirmed }_{i}+\varepsilon_{i} \quad i=1,2, \ldots, N
$$


In the research model described by equation (2), the variable Pricei represents the price for copper, aluminum, zinc, nickel, lead, and tin, taken daily from LME, and the variable Confirmedi represents the number of confirmed COVID-19 cases on a daily basis. The regression parameters $\beta 0$ and $\beta 1$ are unknown constants, the random error $\varepsilon i$ represents the stochastic term, and $\mathrm{N}$ is the size of the base set $(\mathrm{N}=6)$.

\section{EMPIRICAL RESULTS}

SPSS 17.0 software package was used for statistical data processing. Before starting the regression analysis, the fulfillment of the presumptions necessary for its implementation was checked. Figure 1 shows Scatter diagrams for all dependent variables $\mathrm{Yi}, \mathrm{i}=1, \ldots, 6$ (copper, aluminium, zinc, nickel, lead, and tin), for all three observed research periods.

Figure 1. Scatter diagrams
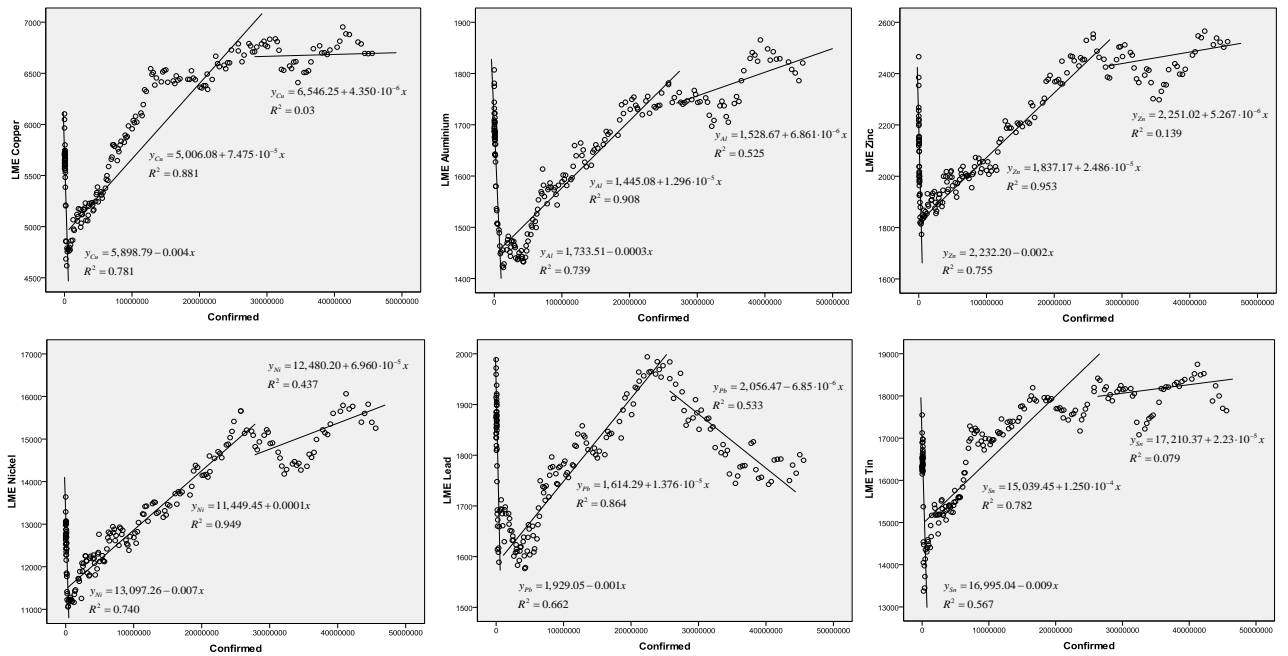

Source: Results of analysis conducted by the authors in SPSS 17.0 software package

Based on the diagram, the fulfillment of some basic assumptions for Simple linear regression is estimated. It can be noticed that the connections between the variables more or less look linear, which satisfies the precondition of linearity because the points on the diagram are grouped around straight lines.

In the first research period, with the increase of the value of the independent variable $(\mathrm{X})$, the values of all dependent variables (Yi) significantly decrease. In the second observed period, with the increase of 
the value of the independent variable $(\mathrm{X})$, the values of all dependent variables (Yi) increase significantly. In the third observed period, it is noticeable that with the increase of the value of the independent variable $(\mathrm{X})$, the values of the dependent variables (Yi) increase, except for "Lead" where a decrease in the value is recorded. Also, Scatter diagrams suggest that the assumption of homoscedasticity (homogeneity of variance) was met for all the three observed research periods because the variability of variables Yi remains relatively constant when switching from one value of variable $X$ to another, i.e. the width of the group of points is approximately constant from one end of the diagram to the other. As it was determined that the ratio of variables is approximately linear for all three observed research periods and that the results are evenly distributed, it can be concluded that the initial data are suitable for regression analysis. Assumption of residual normality (normal residual distributions) is checked based on the constructed histogram of standard residuals (Figure 2) and diagram Normal Probability Plot (P-P) of Regression Standardised Residual (Figure 3).

Figure 2. Histogram of standard residues
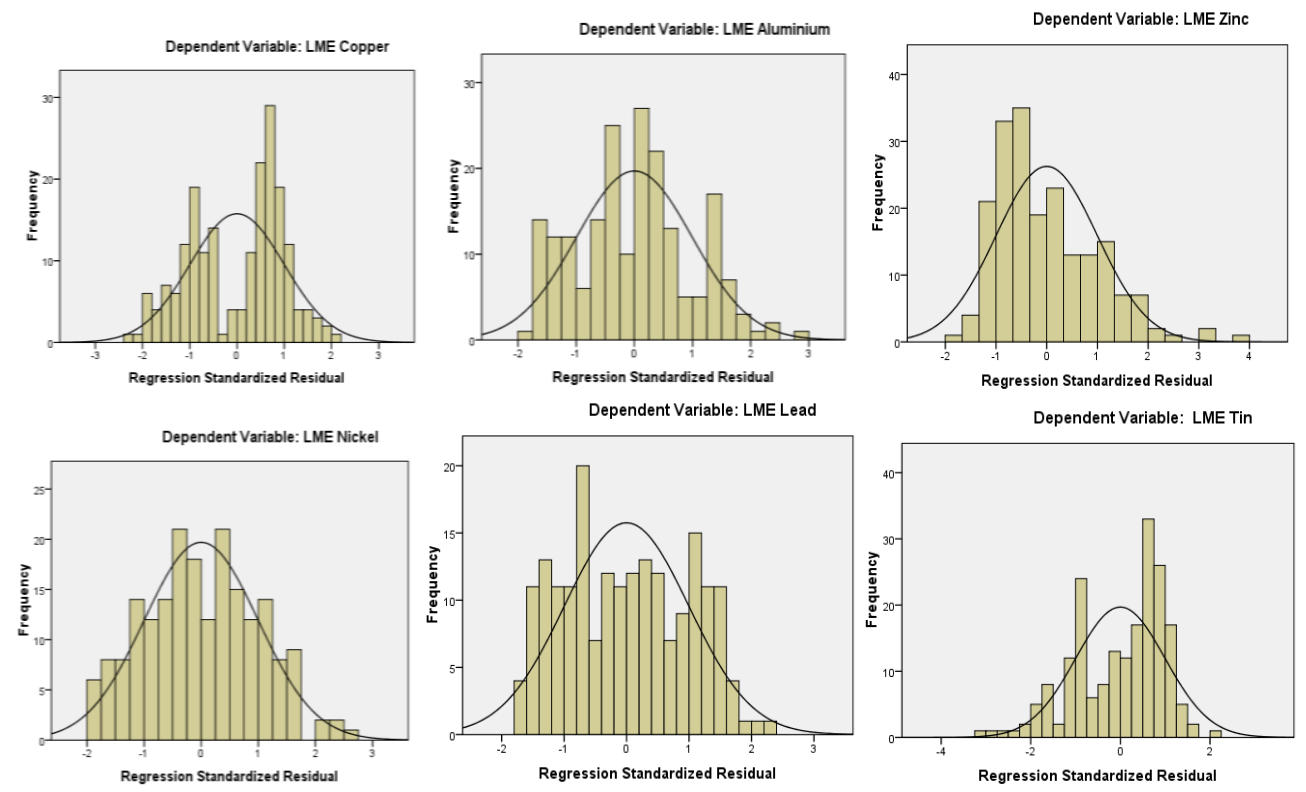

Source: Results of analysis conducted by the authors in SPSS 17.0 software package

Based on the histogram for dependent variable "Zinc", it can be concluded that there are no large deviations of the residuals from the normal distribution except for two residuals that are significantly distant from the others (approximately +3 or +4 standard deviations from the average values). 
These are atypical points because their values are significantly different from the others. A similar conclusion can be drawn for other dependent variables. For the dependent variable "Tin" there is one atypical point that is approximately -3 standard deviations distant from the average value. For dependent variables copper, aluminum, nickel, and lead, no atypical points were identified.

Figure 3. Normal P-P Plot of Regression Standardized Residual
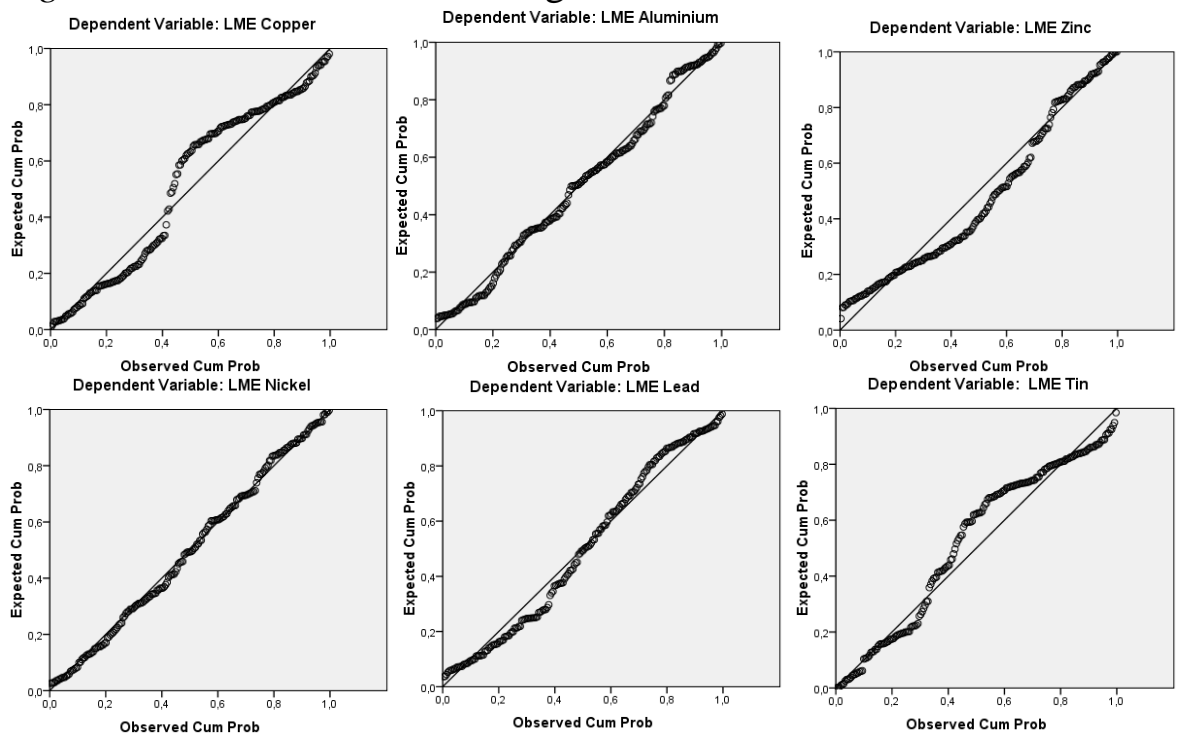

Source: Results of analysis conducted by the authors in SPSS 17.0 software package

Another visual method to check the assumption of residual normality is provided by the graphs shown in Figure 3. It can be seen in the graphs that for all dependent variables, the points lie on an approximately straight diagonal line from the lower left to the upper right corner of the diagram. This leads to the conclusion that there are no large deviations from normality, i.e. the assumption of residual normality has been confirmed. Based on a visual review of the data presented on the Scatter diagrams of standardized residues, it can be seen that most of the residuals are accumulated in the center around point 0 . Also, it is noticeable that there are some atypical points, i.e. that there are cases with standardized residual greater than +3.3 and smaller than -3.3 . As this is a large sample, and only a few atypical residuals have been found, they can be tolerated. After checking, it can be concluded that initial assumptions of linear regression are not violated, although there are some atypical points with a standardized residual greater than +3.3 and less than -3.3 (Barberis,.1998). 
Analysis of the data in Table 1 shows that there is a linear relationship between the independent variable confirmed and the dependent variables copper, aluminum, zinc, nickel, lead, and tin, for all three observed research periods. The strength of the relationship is determined by case analysis of the regression model. The values of the Pearson correlation coefficient (r), shown in columns $|\mathrm{R}|$ in Table 1, represent the strength of the relationship between the independent variable (X) and dependent variables (Yi).

Table 1. Model Summary

\begin{tabular}{|c|c|c|c|c|c|c|c|c|c|}
\hline Model & $|\mathrm{R}|$ & R Square & $\begin{array}{l}\text { Types/ } \\
\text { Strength }\end{array}$ & $|\mathrm{R}|$ & R Square & $\begin{array}{l}\text { Types/ } \\
\text { Strength }\end{array}$ & $|\mathrm{R}|$ & R Square & $\begin{array}{l}\text { Types/ } \\
\text { Strength }\end{array}$ \\
\hline $\begin{array}{l}\text { Dependent } \\
\text { variables }\end{array}$ & \multicolumn{3}{|c|}{ First period } & \multicolumn{3}{|c|}{ Second period } & \multicolumn{2}{|c|}{ Third period } & \\
\hline Copper & 0.884 & 0.781 & - strong & 0.939 & 0.881 & $\begin{array}{l}+ \text { very } \\
\text { strong }\end{array}$ & 0.173 & 0.030 & $\begin{array}{l}+ \text { very } \\
\text { weak }\end{array}$ \\
\hline Aluminium & 0.859 & 0.739 & - strong & 0.953 & 0.908 & $\begin{array}{l}+\quad \text { very } \\
\text { strong }\end{array}$ & 0.725 & 0.525 & + strong \\
\hline Zinc & 0.869 & 0.755 & - strong & 0.976 & 0.953 & $\begin{array}{l}+\quad \text { very } \\
\text { strong }\end{array}$ & 0.373 & 0.139 & + weak \\
\hline Nickel & 0.860 & 0.740 & - strong & 0.974 & 0.949 & $\begin{array}{l}+\quad \text { very } \\
\text { strong }\end{array}$ & 0.661 & 0.437 & $\begin{array}{l}+ \\
\text { moderat } \\
\text { e }\end{array}$ \\
\hline Lead & 0.814 & 0.662 & - strong & 0.929 & 0.864 & $\begin{array}{l}+\quad \text { very } \\
\text { strong }\end{array}$ & 0.730 & 0.533 & - strong \\
\hline Tin & 0.753 & 0.567 & - strong & 0.884 & 0.782 & + strong & 0.281 & 0.079 & $\begin{array}{l}+ \text { very } \\
\text { weak }\end{array}$ \\
\hline
\end{tabular}

Source: Results of analysis conducted by the authors in SPSS 17.0 software package

The obtained values of the coefficient $r$, for the first observed period of the research, indicate that there is a strong, negative, linear relationship between the number of confirmed cases of COVID-19 (confirmed) and the price for copper, aluminium, zinc, nickel, lead and tin, because they amount to $0.884,0.859,0.869,0.860,0.814$ and 0.753 , respectively. For the second observed period of research, it's noticed that there is a very strong, positive, linear relationship between confirmed and prices for copper, aluminum, zinc, nickel, and lead, because the values for $r$ are $0.939,0.953,0.976,0.974$, and 0.929 , respectively. Also, there is a strong, positive, linear relationship between confirmed and the price for tin $(\mathrm{r}=0.884)$. For the third observed period, there is a strong, negative, linear relationship between confirmed and the price for lead $(r=0.730)$; strong, positive, linear relationship between confirmed and the price for aluminium ( $r=0.725)$; moderate, positive, linear relationship between confirmed and the price for nickel ( $\mathrm{r}=0.661)$; weak, positive, linear relationship between confirmed and the price for zinc $(\mathrm{r}=0.373)$; and very weak, positive, linear relationship between confirmed and the price for copper $(\mathrm{r}=0.173)$ and tin $(\mathrm{r}=0.281)$. 
The relative measure of the representativeness of the regression line is determined by the coefficient of determination (R-square or R2). R-squared is a goodness-of-fit measure for linear regression models. It's a statistical measurement that examines how differences in one variable can be explained by the difference in a second variable, when predicting the outcome of a given event, ie estimating how strong the linear relationship is between two variables. In other words, R-squared indicates the percentage of the variance in the dependent variable that the independent variables explain collectively. The strength of the relationship is measured on a $0-1$ scale. For $\mathrm{R} 2=1$, all empirical values yi are on the regression line, i.e. the explained variability is equal to the total. Then the variations of the variable $\mathrm{Y}$ are completely explained by the regression line, and there is no influence of other factors. As the value of R-squared approaches zero, the share of explained variability decreases, and the regression line represents the data less and less.

Table 1 shows the values of the explained variability of the dependent variables copper, aluminum, zinc, nickel, lead and tin by the independent variable confirmed, for all three observed periods. For example, for the second observed period, the value R2 $=0.881$ means that the independent variable confirmed explains $88.1 \%$ of the variability of the dependent variable copper, etc.

After testing the null hypothesis, that R2 in population equals 0 , it was observed that the model achieves statistical significance $(p=0.000<=0.001)$, for all dependent variables, for all three observed research periods. This means that the results of the overall regression are significant and that the regression model is good because the independent variable confirmed statistically well predicts dependent variables copper, aluminum, zinc, nickel, lead, and tin. The actual relationship between the dependent and independent variable can be approximated by a regression model (linear regression equations). The equations for predicting prices for copper, aluminum, zinc, nickel, lead, and tin, based on the number of confirmed cases of coronavirus infection (confirmed), for all three time periods, are shown in Figure 1.

For example, a simple linear regression equation for copper, for the second observed period, according to equation (1), can be written as follows $\mathrm{yCu}=5,006.08+7.475 \cdot 10-5 \mathrm{x}$. The simple linear regression model, according to equation (2), can be written as:

$$
\text { PriceCu=5,006.08+7.475·10-5Confirmed }
$$

The interpretation of the linear equation is as follows. The parameter $\beta 0=5,006.08$ represents the estimated price for copper at the beginning of the second observed period (March 23, 2020). The parameter $\beta 1=7.475 \cdot 10-5$ is 
the coefficient of the line direction slope (coefficient), and represents the expected change in the value of the dependent variable for the unit change in the value of the independent variable. In this particular case, 7.475.10-5 represents the expected increase in copper price along with an increase in the number of infected by unit value, i.e. US\$ 74.75 per tonne per 1.000 .000 confirmed cases of coronavirus infection. Conclusions for other dependent variables can be drawn analogously.

\section{DISCUSSION, IMPLICATIONS AND LIMITATIONS}

By monitoring the behavior of non-ferrous metals prices in the London Stock Exchange and the reactions to the events related to the spread of COVID-19 disease from January 22 to October 30, 2020, it can be noticed that some significant changes took place. The results of the conducted research confirm that there is a linear relationship between the independent variable confirmed and the dependent variables copper, aluminum, zinc, nickel, lead, and tin, for all three observed research periods.

When analyzing the results of the first research period, it must be borne in mind that the outbreak of coronavirus in Wuhan disrupted the Chinese economy and forced the Chinese authorities to take drastic measures to prevent the spread of the disease. The shutdown and reduced production volume together led to reduced demand for raw materials such as metals, with the end result of falling metal prices on the stock exchange, which is confirmed by the results of this study. Namely, for the first observed period, there is a strong, negative, linear relationship between the number of confirmed cases of COVID-19 and the price for copper, aluminium, zinc, nickel, lead and tin, because the Pearson correlation coefficient values are $0.884,0.859,0.869,0.860,0.814$ and 0.753 , respectively.

The values of the explained variability of the dependent variables copper, aluminum, zinc, nickel, lead, and tin by the independent variable confirmed are $78.1 \%, 73.9 \%, 75.5 \%, 74.0 \%, 66.2 \%$, and $56.7 \%$, respectively. In the context of economic globalization, the great spread of the pandemic forced most countries and regions to adopt strict control measures, which inevitably affected the normal operation of the globalized production and industrial systems and sharp drop in metal prices in February and March 2020. The results of the regression analysis documented the negative and significant impact of the coronavirus crisis on the stock market response, which was proven in studies. (Al-Awadhi et al., 2020; Ashraf, 2020; Laing, 2020; Ramelli and Wagner, 2020; Zhang et al., 2020; Yin, 2020).

For the second observed period, there is a very strong, positive, linear relationship between the number of confirmed cases of COVID-19 and 
prices for copper, aluminum, zinc, nickel, and lead, because the Pearson correlation coefficient values are 0.939, 0.953, 0.976, 0.974, and 0.929, respectively. Also, there is a strong, positive, linear relationship between the number of confirmed cases of COVID-19 and the price for Tin ( $r=0.884)$.

The results obtained for the second research period have strong support in the reopening of the Chinese market as well as in government stimulus packages taken to boost the economies affected by the coronavirus and in the process of unlocking most countries in May 2020. In addition, China's rising demand for metals due to infrastructure investment and investors' hopes for recovery further argue that the values of the explained variability of the dependent variables copper, aluminum, zinc, nickel, lead, and tin by the independent variable confirmed are $88.1 \%, 90.8 \%, 95.3 \%, 94.9 \%, 86.4 \%$, and $78.2 \%$, respectively.

Unlike the previous research period, for the third observed period, a linear relationship between the independent variable confirmed (the number of confirmed cases of COVID-19) and the dependent variables were observed as follows: a strong, negative for lead $(\mathrm{r}=0.730)$; strong, positive, for aluminium $(\mathrm{r}=0.725)$; moderate, positive for nickel $(\mathrm{r}=0.661)$; weak, positive for zinc $(\mathrm{r}=0.373)$; and very weak, positive for copper $(\mathrm{r}=0.173)$ and tin $(r=0.281)$. The values of the explained variability of the dependent variables copper, aluminum, zinc, nickel, lead, and tin by the independent variable confirmed are $3.0 \%, 52.5 \%, 13.9 \%, 43.7 \%, 53.3 \%$, and $7.9 \%$, respectively.

The obtained results are supported by the new coronavirus attack with a record number of infected in European countries, measures taken to prevent the spread of the disease, and repair of the negative economic consequences caused by the health crisis. An additional argument is that China accounts for about half of the world demand for copper, making its manufacturing sector a primary driver of prices despite the increase in the number of confirmed COVID-19 cases.

Based on the regression equation (1) for the third observed period, the expected price increase for copper, aluminium, zinc, nickel, and tin, with an increase in the number of coronavirus infections by $1,000,000$, is the US\$ 6.55, US\$ 6.86, US\$ 5.27, US\$ 69.60, and the US\$22.30 per tonne, respectively.

Based on the regression equation (1) for the third observed period, the expected decline in lead prices, with an increase in the number of coronavirus infections by $1,000,000$, is US\$ 6.85 per tonne.

Based on a simple linear regression model, equation (2), the predicted market price for copper, aluminum, zinc, nickel, lead, and tin, with an increase in the number of infections to $50,000,000$, would be the US\$ 
6,763.75; US\$ 1,871.72; US\$ 2,514.37; US\$ 15,960.20; US\$ 1,713.97; and the US\$ $18,325.37$ per tonne, respectively.

\section{Implications and limitations}

The conducted research has given clear theoretical implications on how information about the public health crisis is relevant for negative market reactions. Through the contribution to economic theory, scientific literature has been expanded, and the results of the study have confirmed the hypothesis that stock exchanges around the world reacted negatively to the COVID-19 pandemic in the first months of 2020. Accordingly, by considering the characteristics of the pandemic and the assumption that price stability in the metal market depends on the degree of COVID-19 control in the future, this can be the basis of some future research. This study had the ambition to provide knowledge and information relevant to the planning of measures, i.e. a response to the economic challenges posed by future pandemics as a contribution to the community. Planning measures in advance would reduce the uncertainty and panic that lead to price instability of non-ferrous metals in the stock market.

The purpose of the study was to explore the relationship between the number of confirmed cases of COVID-19 and the price of non-ferrous metals copper, aluminum, zinc, nickel, lead, and tin on the London Stock Exchange. As no research is free from its own limitations, so does this one have its own that may have influenced the results. The first limitation of the study is the inclusion of only one independent variable in the model - the number of confirmed cases of COVID-19. In addition to this independent variable, future studies could also include information related to COVID-19, such as fake news, media coverage, and death toll. Another limitation of the study is the applied methodology. Namely, the adopted statistical approach in the paper was a simple linear regression. Therefore, in order to examine the impact of COVID-19 on the trend of metal prices in the market, future studies could apply other approaches, such as multiple linear regression, VAR methodology, Panel data analysis. Given the limitations, this research is an attempt by the authors to expand scientific literature and indicate that there is room for future studies. Further research in the area stems from the authors' expectations that these limitations will not have a negative impact on the applicability or usefulness of the study results. 


\section{CONCLUSION AND RECOMMENDATIONS}

The new coronavirus has created notable shock waves in both commodity and financial markets. On the other hand, the drop in metal prices clearly shows short-term and long-term severe consequences in the industry which, unfortunately, cannot be avoided. All this leads to a global decline in economic activity. In this context, the aim of the paper was to determine the impact of COVID-19, i.e. number of confirmed cases on nonferrous metal prices on the London Stock Exchange. By monitoring the behavior of non-ferrous metal prices from January 22 to October 30, 2020, it is clear that there were significant changes as a response to the events related to the spread of coronavirus.

Based on the research results, metal prices experienced a decline after the report of the World Health Organisation and introduction of restrictive measures, and they increased after hints or adoption of measures to cover the negative economic consequences of the health crisis. Also, the results suggest that prices of metal and, therefore, markets are less responsive to the health crisis after the introduction of measures and increased certainty which they operate with. The investigation of the link between the pandemic and volatility of non-ferrous metal prices is key to understanding market policy measures and the global economy. For this reason, in order to mitigate future shocks and prevent a large drop in prices in the non-ferrous metal market, it is necessary to have answers in advance to the economic challenges caused by the public health crisis. Therefore, the authors hope that the conducted research sheds a new light on how the information on the number of confirmed cases and public health crisis is relevant for negative market reactions and suggest the need to establish a strong coordinated global response.

\section{REZIME \\ PANDEMIJA COVID-19 I NESTABILNOST ROBNIH TRŽIŠTA: DOKAZI SA LONDONSKE BERZE METALA}

Rad pruža uvid u ponašanje cena obojenih metala na Londonskoj berzi tokom zdravstvene krize izazvane širenjem koronavirusa u period 22 januar 30 oktobar 2020. Cilj rada je da se utvrdi statistički značajna relacija između broja potvrđenih slučajeva COVID-19 i cena obojenih metala bakra, aluminijuma, cinka, nikla, olova i kalaja. Da bi se došlo do rezultata, u radu je korišćena prosta linearna regresija. Nakon izveštaja Svetske zdravstvene organizacije i uvođenja restriktivnih mera za sprečavanje širenja koronavirusa, rezultati regresije podržavaju pad cena obojenih metala na 
Londonskoj berzi. Takođe, rezultati sugerišu da su preduzete mere za saniranje negativnih ekonomskih posledica zdravstvene krize povezane sa rastom cena obojenih metala. Kako je ekonomski uticaj ove pandemije još uvek neizvestan, kroz indikativni pregled uticaja, sprovedeno istraživanje daje i mogućnost predviđanja cene obojenih metala u narednom vremenu. Pretpostavka da stabilnost cena na tržištu metala zavisi od stepena kontrole pandemije COVID-19, može biti osnova za neka buduća istraživanja.

Ključne reči: pandemija COVID-19, robna tržišta, cena obojenih metala, jednostavna linearna regresija

\section{REFERENCES}

1. Al-Awadhi, A.M., Al-Saifi, K., Al-Awadhi, A., Alhamadi, S. (2020). Death and contagious infectious diseases: Impact of the COVID-19 virus on stock market returns. Journal of Behavioral and Experimental Finance, 27:100326, 1-5. DOI:10.1016/j.jbef.2020.100326

2. Albulescu, C.T. (2020). Coronavirus and Oil Price Crash. SSRN Electronic Journal, 1-13, Retrieved October 05, 2020, from https://papers.ssrn.com/sol3/ papers.cfm?abstract_id=3553452. DOI: $10.2139 / \mathrm{ssrn} .3553452$

3. Ashraf, B. N. (2020). Economic impact of government interventions during the COVID-19 pandemic: International evidence from financial markets. Journal of Behavioral and Experimental Finance, 27:100371, 1-9. https://doi.org/10.1016/ j.jbef.2020.100371

4. BBC, (2020). Global economy will suffer for years to come, says OECD. Retrieved September 05, 2020, from https://www.bbc.com/news/business-52000219

5. Baldwin, R., Weder di Mauro, B. (2020). Economics in the Time of COVID-19. Centre for Economic Policy Research

6. Baker, S. R., Bloom, N., Davis, S. J., Kost, K., Sammon, M., Viratyosinm, T. (2020). The unprecedented stock market reaction to COVID-19. The Review of Asset Pricing Studies, 0, 1-17. https://doi.org/10.1093/rapstu/raaa008

7. Barberis, N., Shleifer, A., Vishny, R. (1998). A model of investor sentiment. Journal of Financial Economics, 49(3), 307-343.

8. Blendon, R. J., Benson, J. M., DesRoches, C. M., Raleigh, E., TaylorClark, K. (2004). The public's response to severe acute respiratory syndrome in Toronto and the United States. Clinical Infectious Diseases, 38(7), 925-931. https://doi.org/10.1086/382355 
9. Conlon, T., McGee, R. (2020). Safe haven or risky hazard? Bitcoin during the Covid-19 bear market. Finance Research Letters, 35, 1016072, 1-5. https://doi.org/10.1016/j.frl.2020.101607

10. Corbet, S., Larkin, C., Lucey, B. (2020). The contagion effects of the COVID-19 pandemic: Evidence from gold and cryptocurrencies. Finance Research Letters, 35, 1015542, 1-7. https://doi.org/10.1016/j.frl.2020.101554

11. European Central Bank, Retrieved September 20, 2020, from https://www.ecb. europa.eu/home/html/index.en.html

12. Gkillas, K., Gupta, R., Pierdzioch, C. (2020). Forecasting realized oilprice volatility: The role of financial stress and asymmetric loss. Journal of International Money and Finance, 4(C) DOI:10.1016/j.jimonfin.2020.102137.

13. Goodell, J. W. (2020). COVID-19 and finance: Agendas for future research. Finance Research Letters, 35:101512, 1-5. https://doi.org/10.1016/j.frl.2020.101512.

14. Groß-Klußmann, A., Hautsch, N. (2011). Predicting Bid-Ask Spreads Using Long Memory Autoregressive Conditional Poisson Models. Retrieved October 05, 2020, from SSRN: https://ssrn.com/abstract=1884237 orhttp://dx.doi.org/10. 2139/ssrn.1884 237

15. International Monetary Found, Retrieved September 20, 2020, https://www. imf.org/en/Topics/imf-and-covid19

16. Iyke, B. N. (2020a). The disease outbreak channel of exchange rate return predictability:Evidence from COVID-19. Emerging Markets Finance and Trade, 56(10), 2277-2297. DOI:10.1080/1540496X.2020.1784718

17. Iyke, B. N. (2020b). COVID-19: The reaction of US oil and gas producers to the pandemic. Energy Research Letters, 1(2). https://doi.org/10.46557/001c.13912

18. Ji, Q., Zhang, D., Zhao, Y. (2020). Searching for safe-haven assets during the COVID-19 pandemic. International Review of Financial Analysis, 71:1015262, 1-10. https://doi.org/10.1016/j.irfa.2020.101526

19. Johns Hopkins University Medicine, (2020). Coronavirus Resource Center: World Map. Johns Hopkins University and Medicine. Retrieved September 20, 2020, https://coronavirus. jhu.edu/map.html

20. London metal exchange, Retrieved October 05, 2020, from https://www.lme.com/en-GB/Metals/Non-ferrous\#tabIndex $=0$

21. Lyocsa, Š., Baumohl, E., Vyrost, T., Molna, P. (2020). Fear of the coronavirus and the stock markets. Finance Research Letters, 36:101735, https://doi. org/10.1016/j.frl.2020.101735 
22. McKibbin, W. J., Fernando, R. (2020). The Global Macroeconomic Impacts of COVID-19: Seven Scenarios. SSRN Electronic Journal. https://doi.org/10.2139/ssrn.3547729

23. Mirzaa, N., Naqvib, B., Rahata, B., Rizvi, A.K.S. (2020). Price reaction, volatility timing and funds' performance during Covid-19. Finance Research Letters, 36:101657, 1-8. https://doi.org/10.1016/j.frl.2020.101657

24. Ramelli, S., Wagner, A. F. (2020). Feverish stock price reactions to covid-19. Swiss Finance Institute, Research Paper No. 20-12. Retrieved September 15, 2020, from https://papers.ssrn.com/sol3/papers.cfm?abstract_id =3550274

25. Reuters, (2020). IMF chief says pandemic will unleash worst recession since Great Depression. Retrieved from: https://www.reuters.com/article/us-health-coronavirus-imf/imfchiefsays-pandemic-will-unleash-worst-recession-since great depressionid USKCN21R1SM

26. Reilly, J. (2020). Treatment considerations for coronavirus (COVID-19). Hospital Practice, 48:3, 119-120, DOI: 10.1080/21548331.2020.1754618

27. Saadat, S., Rawtani, D., Hussain. M. C. (2020). Environmental perspective of COVID-19. Science of the Total Environment, 728, 138870. doi:10.1016/j.scitotenv.2020.138870.

28. Salisu, A. A., Akanni, L., Ibrahim Raheem, I. (2020a). The COVID-19 global fear index and the predictability of commodity price returns. Journal of Behavioral and Experimental Finance, 27:100383, 1-7. https://doi.org/10.1016/j. jbef.2020.100383

29. Sharif, A., Aloui, C., Yarovaya, L. (2020). COVID-19 pandemic, oil prices, stock market, geopolitical risk and policy uncertainty nexus in the US economy: Fresh evidence from the wavelet -based approach. International Review of Financial Analysis, 70:101496, 1-9. https://doi.org/10.1016/j.irfa.2020.101496

30. World Health Organization (WHO), Retrieved May 05, from 2020, https://www.who.int/news-room/detail/27-04-2020-whotimeline-covid19

31. Torun, E., Chang, T. P., Chou, R.Y. (2020). Causal relationship between spot and future prices with multiple time horizons: A nonparametric wavelet Granger causality test. Research in International Business and Research 52, 101-115. DOI: 10.1016/j.ribaf.2019.101115

32. UNCTAD, (2020). Global trade impact of coronavirus(COVID-19) epidemic. Trade and Development Report Update, Retrived September 05, 2020 from: https://unctad.org/system/files/officialdocument/ditcinf2020d1.pdf 1-7. 
33. Wilder-Smith, A., Freedman, D. O. (2020). Isolation, quarantine, social distancing and community containment: Pivotal role for old-style public health measures in the novel coronavirus (2019-nCoV) outbreak. In Journal of Travel Medicine, 27(2), 1-4. https://doi.org/10.1093/jtm/taaa020

34. Wu, K. J. Z., Xu, M., Yang, L. (2020). Can crude oil drive the comovement in the international stock market? Evidence from the partial wavelet coherence analysis. The North American Journal of Economics and Finance, 53, 101-119. https://doi.org/10.1016/j.najef.2020.101194

35. World Bank, (2020). Commodity Markets Outlook. Implications of COVID-19 for Commodities. Publishing and Knowledge Division.World Bank: Washington. https://openknowledge.worldbank.org/bitstream/handle/10986/33624/C MO-April-020.pdf.

36. Yarovaya, L., Matkovskyy, R., Jalan, A. (2020). The effects of a 'black swan' event (COVID-19) on herding behavior in cryptocurrency markets: Evidence from cryptocurrency USD, EUR, JPY and KRW markets. SSRN: https://ssrn.com/abstract=3586511.

37. Yin, Z. C., Lu, Z. H., Pan, X. B. (2020). The impact of the Sino-US trade war on China's stock market: An event-based analysis. Journal of Management, 33(1), 18-28. doi:10.19808/j.cnki.41-1408/F.2020.01.003.

38. Zhang, D., Hu, M., Ji, Q. (2020). Financial markets under the global pandemic of COVID-19. Finance Research Letters, 36:101528, https://doi.org/10.1016/j.frl.2020.101528

Ovaj rad je primljen 04.01.2021., a na sastanku redakcije časopisa prihvaćen za štampu 28.06.2020. godine. 